American Journal of Biochemistry and Biotechnology 1 (3): 121-124, 2005

ISSN 1553-3468

(C) 2005, Science Publications

\title{
Role of Plasmid in Production of Acetobacter Xylinum Biofilms
}

\author{
Abbas Rezaee, Sanaz Solimani and Mehdi Forozandemogadam \\ Faculty of Medical Sciences, Tarbiat Modares University, Tehran, Iran
}

\begin{abstract}
Acetobacter xylinum has the ability to produce cellulotic biofilms. Bacterial cellulose is expected to be used in many industrial or biomedical materials for its unique characteristics. A. xylinum contains a complex system of plasmid DNA molecules. A 44 kilobases $(\mathrm{kb})$ plasmid was isolated in wild type of A. xylinum. To improve the cellulose producing ability of A. xylinum, role of the plasmid in production of cellulose was studied. The comparisons between wild type and cured cells of $A$. xylinum showed that there is considerably difference in cellulose production. In order to study the relationship between plasmid and the rate of cellulose production, bacteria were screened for plasmid profile by a modified method for preparation of plasmid. This method yields high levels of pure plasmid DNA that can be used for common molecular techniques, such as digestion and transformation, with high efficiency.
\end{abstract}

Key words: Acetobacter xylinum, plasmid, biofilm, cellulose, curing

\section{INTRODUCTION}

Cellulose is the most abundant biopolymer on earth, recognized as the major component of plant biomass, but also a representative of microbial extracellular polymers ${ }^{[1]}$. Bacterial Cellulose (BC) belongs to specific products of primary metabolism and is mainly a protective coating, whereas plant cellulose plays a structural role ${ }^{[2]}$. Cellulose is synthesized by bacteria belonging to the genera Acetobacter, Rhizobium, Agrobacterium and Sarcina. Its most efficient producers are Gram-negative, acetic acid bacteria Acetobacter xylinum (reclassified as Gluconacetobacter xylinus), which have been applied as model microorganisms for basic and applied studies on cellulose ${ }^{[3]}$. Acetobacter xylinum produce an extracellular gel- like material or pellicle, which comprises of a random assembly of cellulose ribbons composed of a number of microfibrils. Extracellularly synthesized microbial cellulose differs from plant cellulose with respect to its high crystallinity and purity (free of legnin and other biogenic products), high water-absorption capacity and mechanical strength in the wet state ${ }^{[4]}$. Several application have been proposed for this cellulosic layer. Because of the unique properties, resulting from the ultrafine reticulated structure, BC has found a multitude of applications in paper, textile and food industries and as a biomaterial in cosmetics and medicine ${ }^{[5]}$. One of applications of bacterial cellulose is use as burn infection and heal lesions. Modern medical biotechnology has accepted artificial skins as a valid prospect. Several properties advantageous for its use as a temporary skin substitute were recognized for the biofilms ${ }^{[3,5]}$. Its successful application by dermatologists and plastic surgeons included human second and third degree skin burns, skin grafts, face peelin, infectious enhanced propertions of fibroblasts, collagen, blood vessels and granulation tissue as a result of the cellulosic pellicle use were seen in the healing wound. Wider application of this polysaccharide is obviously dependent on the scale of production and its cost. Therefore, basic studies run together with intensive research on strain improvement and production process development. In the research was studied, about role of plasmid on production of cellulose by elimination of plasmid DNA ,curing,. Curing is an important step in identifying the phenotypic traits encoded by a given plasmid. Plasmid curing studies have been focused on Escherichia coli, Salmonella typhimurium, Staphylococcus aureus, to a lesser extent, strains of degradative Pseudomonads. A multitude of different chemicals including inhibitors of DNA replication, intercalating drugs, bacterial surface agents and Sodium Dodecyl Sulphate (SDS) at elevated temperature has been used as curing agents. However, apart from its spontaneous loss, very little is known about how to cure the plasmids of A. xylinum. The plasmids may prove biotechnologically important as it has been implicated in the production of microbial cellulose $^{[6]}$. In this study, Acridin orange properties were exploited for curing of the A. xylinum plasmid.

\section{MATERIALS AND METHODS}

Bacterium: A freeze-dried culture of A. xylinum was obtained from the Persian Culture Type Collection of

Corresponding Author: Abbas Rezaee, Faculty of Medical Sciences, Tarbiat Modares University, Tehran, Iran Fax: +98 218013030 
Microorganisms. Following recultured in Schramm Hestrin (SH) medium, the culture was found to be pure and biochemical and morphological tests revealed that the organism conforms to the generic description listed for A. xylinum in Bergey's Manual of Systematic Bacteriology ${ }^{[7]}$.

Culture conditions: The bacteria was inoculated with $10^{8}$ to $10^{9}$ cell per mL in $\mathrm{SH}$ medium at $28^{\circ} \mathrm{C}$ for a week under static conditions to produce cellulose pellicles. For plasmid isolation, Acetobacter xylinum was grown in SH agar.

Determination of wet and dry weights of pellicles:The pellicle was lifted from the plate with a bent glass rod and allowed to drip for $30 \mathrm{~min}$. The pellicle was then placed in a pre weighed plastic weighing plate. The weighing plate and pellicle were then placed in a drying oven for $6 \mathrm{~h}$ at $80^{\circ} \mathrm{C}$. After being dried and removed from the oven, the weighing boat and pellicle were weighed immediately. Pellicles were also washed with running tap water prior to the wet and dry weight determinations. There were no percentage differences between the wet and dry weight comparisons of pellicles that had not been washed before being allowed to drip for $30 \mathrm{~min}^{[8]}$.

Rapid screening for plasmids: A small number of cells were picked by touching a colony with a toothpick. They were then inoculated into a microfuge tube containing $300 \mu \mathrm{L}$ of SH broth. After overnight growth, the cells were pelleted in a microfuge (10,000 rpm, $2 \mathrm{~min})$. The cells were then suspended by vortexing in $20 \mu \mathrm{L}$ of gel-loading $\operatorname{mix}(0.25 \%$ bromophenol blue and 30\% glycerol). Then $40 \mu \mathrm{L}$ each of chloroform and phenol (saturated with $1.0 \mathrm{M}$ Tris- $\mathrm{HCl}, \mathrm{pH}$ 8.0) was added. The mixture was vortexed at full speed for $1 \mathrm{~min}$ followed by centrifugation for $10 \mathrm{~min}$ at $12,000 \mathrm{rpm}$. Then $10 \mu \mathrm{L}$ of the aqueous fraction was subjected to electrophoresis on $0.7 \%$ agarose minigel $(5.2 \times 6.0 \mathrm{~cm})$ with TAE buffer (40 mM Tris-acetate, pH 8.0 containing $2 \mathrm{mM}$ $\mathrm{Na}_{2}$-EDTA) at 100 volts for $30 \mathrm{~min}$. The gel was stained with ethidium bromide $\left(0.5 \mu \mathrm{gmL}^{-1}\right)$ and the DNA bands were visualized under a UV transilluminator.

Plasmid isolation: Plasmid isolation was performed by a modified method of Sambrook ${ }^{[9]}$. The protocol is as follows: Because Acetobacter xylinum produces cellulose in broth culture, $\mathrm{SH}$ medium was used. The bacterium were grown in SH medium supplemented with chloramphenicol, bismuth nitrate and sodium salicylate . The bacteria were suspended by mixing with a vortex mixer in suspension buffer, TE buffer $(10 \mathrm{mM}$ Tris, $1 \mathrm{mM}$ EDTA), pH 8.0. An aliquot $(200 \mu \mathrm{L})$ of freshly prepared lysis buffer $(0.2 \mathrm{~N} \mathrm{NaOH}$ containing $3 \%$ SDS) was added and after the contents were rapidly and thoroughly mixed without vortexing, the Eppendorf tube was allowed to stand on ice for $5 \mathrm{~min}$. An aliquot $(150 \mu \mathrm{L})$ of ice-cold neutralizing solution (acidic potassium acetate constituted by mixing $11.5 \mathrm{~mL}$ of glacial acetic acid, $28.5 \mathrm{~mL}$ of distilled water and $60 \mathrm{~mL}$ of $5 \mathrm{M}$ potassium acetate) was added and the contents were gently mixed by inversion to neutralize the $\mathrm{pH}$ in the cell lysate which was noted to be viscous. The SDS and associated proteins as well as cell debris were then removed by centrifugation at $12000 \mathrm{rpm}$ for $5 \mathrm{~min}$ at $4^{\circ} \mathrm{C}$. The supernatant containing the plasmid DNA and possibly some RNA was transferred into a fresh Eppendorf tube containing $20 \mu \mathrm{L}$ of DNase-free RNase $\left(10 \mathrm{mgmL}^{-1}\right)$ to ensure the removal of any traces of RNA. After the addition of DNase-free RNase and incubation for $20 \mathrm{~min}$ in $37^{\circ} \mathrm{C}$, an equal volume of phenol/chloroform/isoamyl alcohol (DNA grade) was added to the supernatant. The contents of the Eppendorf tube were mixed gently but thoroughly and then centrifuged at $12000 \mathrm{rpm}$ for $5 \mathrm{~min}$ at $4{ }^{\circ} \mathrm{C}$ in a microfuge. With the aid of a pipette, the supernatant (upper layer) was transferred to a fresh Eppendorf tube and great care was taken to avoid the transfer of the white precipitate present at the interface, if the upper layer was not clear owing to the presence of large quantities of polysaccharides, this step was repeated. Two volumes of ice-cold ethanol were then added to the supernatant and after thorough mixing and incubation at $-70{ }^{\circ} \mathrm{C}$ or room temperature for $60 \mathrm{~min}$, the plasmid DNA was precipitated by centrifugation at maximum speed in a microfuge at room temperature for $10 \mathrm{~min}$, the supernatant was discarded and the Eppendorf tube was then allowed to stand inverted on a paper towel to drain away any excess ethanol. The plasmid DNA pellet was then washed twice with $1 \mathrm{~mL}$ of ethanol $(70 \%)$ at $4{ }^{\circ} \mathrm{C}$ and after discarding the supernatant and removing large droplets of ethanol with the aid of sterile cotton buds or fine tissues, any traces of ethanol were further removed. Electrophoresis of the plasmid was carried out overnight on $0.7 \%$ agarose gels at $3.0 \mathrm{Vcm}^{-1}$ in TAE buffer. Restriction fragments, however, were electrophoresed using TBE buffer at $6.0 \mathrm{Vcm}^{-1}$ for $4 \mathrm{~h}$ as previously described ${ }^{[8,10,11]}$.

Curing of Acetobacter xylinum: Acetobacter xylinum cured by growth at $28^{\circ} \mathrm{C}$ in $\mathrm{SH}$ medium containg a subinhibitory concentration of Acridin orange (5 to $600 \mu \mathrm{g})$. Cultures containing the highest concentration of Acridin orange which growth was clearly visible were diluted and spread into SH plates. Resulting clonies were tested for chloramphenicol sensitivity and electrophoresis. A cell lysate of $A$.xylinum and its cured derivative were cultivate as described in culture conditions of materials and methods and the presence or 
absence of plasmid DNA was tested using agarose gel electrophoresis. A purified sample of A. xylinum plasmid as well as lambda (digested with HindIII) were also included.

Restriction analysis of isolated plasmid DNA: Plasmids isolated from A. xylinum were digested with two restriction enzymes (BamHI and HindIII) at the same time. Aliquots of A. xylinum plasmid DNA, prepared as described above, were digested overnight at $37^{\circ} \mathrm{C}$ with ten units of various restriction enzymes and the fragments thus generated were fractionated by electrophoresis on $0.7 \%$ agarose gel as described above. The bands, which were visualized under ultraviolet light, were compare with standard marker.

\section{RESULTS AND DISCUSSION}

A. xylinum is an acetic acid bacterium which has the ability to produce cellulose extracellurarly. To improve the cellulose-producing ability of A. xylinum, recombinant DNA techniques seems to be proper method. The genus A. xylinum contains several species which are being extensively studied in connection with acetic acid production and cellulose formation ${ }^{[12]}$. There have been several reports of spontaneous mutation in A. xylinum strains affecting both morphological and physiological properties, including loss of the ability to produce cellulose $^{[13,14]}$. Bacteria of this genus are not genitically well characterized and genetic investigations of the phenotypic instabilies have not been reported. To improve the cellulose producing ability of A. xylinum, we studied role of the plasmid in production of cellulose. Most strains of A. xylinum examined contain a rather complex system of plasmids ${ }^{[15]}$. Alterations in the plasmid profile were found in both cellulose negative mutants and cellulose producing revertants of A. xylinum. Cells of A. xylinum produce large amounts of exopolysaccharide, which interferes with the extraction of plasmid DNA ${ }^{[16,17]}$. To repress capsular polysaccharide production, bacteria were cultured in SH medium containing bismuth nitrate and sodium salicylate. After treatment, bacterial cells were more readily lysed in alkaline detergents. The resulting plasmid preparations contained virtually no capsular polysaccharide and relatively small quantities of lipopolysaccharide and protein, yet they produced yields of nucleic acids similar to those of conventional plasmid preparations. Conventional preparations from encapsulated organisms were largely insoluble and appeared as smears following agarose gel electrophoresis, with indefinite plasmid banding. Plasmids prepared by the new method were highly soluble in conventional buffers and exhibited highresolution plasmid banding patterns in agarose gels. The method proved effective with encapsulated or

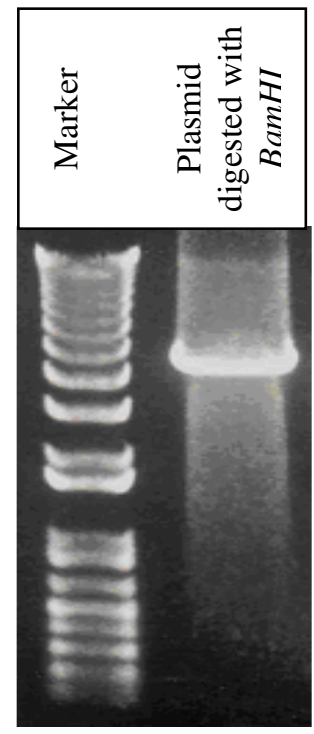

Fig. 1: Agarose gel electrophoresis of A. xylinum plasmid digested with $\mathrm{BamHI}$

mucoid strains of A.xylinum. The method for plasmid isolation was not suitable for each bacteria because of the inhibitory effects of bismuth. Thus, removal of contaminating bacterial surface structures enabled the rapid isolation and characterization of plasmids from mucoid isolates, without the use of organic solvents, $\mathrm{CsCl}$ gradients, or expensive, disposable columns ${ }^{[16]}$. In this study, a simple and rapid method for screening plasmids of A.xylinum has been developed. It is especially useful when sample sizes are large. This method can be achieved in one step simply by phenol/chloroform treatment of the cells pelleted from a volume as small as $300 \mu \mathrm{L}$. The experiment from growing cells to the completion of plasmid extraction can be carried out using the same microfuge tube. The whole procedure takes about $40 \mathrm{~min}$ from harvesting the bacterial cultures to visualization of the DNA bands in agarose gel. Using this method, detected plasmids in A. xylinum have detected. In conclusion, this new method for the isolation of plasmid DNA from lysis-resistant $A$. xylinum has major advantages over the classic method that requires phenol-extraction and cesium chloride gradient centrifugation. This new method does not employ highly toxic reagents, is considerably cheaper and is easy to perform. This method provides high yields of pure DNA, which can be used for restriction analysis, transformation and other molecular techniques. This plasmid isolation technique is also applicable to other Gram-negative bacteria and will improve the efficient engineering of biotechnologically and therapeutically useful A. xylinum recombinants for cellulose production. To construct a physical map, isolate plasmid was cut with 
different restriction endonucleases and subjected to agarose gel electrophoresis. The results showed that it carried single restriction sites for BamHI and HindIII. The molecular size of this plasmid was estimated to be $4.4 \mathrm{~kb}$ based on the sum total of the restriction fragment lengths (Fig. 1). Isolation of the plasmid have been performed reproducibily several times, both from stationary and log-phase cells. This result demonstrates that the band pattern observed in agarose gel electrophoresis are stable characteristics. From present data the following conclusions can be drawn : (I) studied wild type A. xylinum contains a $4.4 \mathrm{~kb}$ plasmid (II) Curing strains have identifiable changes in their cellulose production compared to the wild type. Indicating that these plasmids may be involved in cellulose biosynthesis. Success in isolation of plasmid has shown that allows insertion of foreign genes, demonstrating the potential of A.xylinum being developed into a vector for gene cloning.

\section{REFERENCES}

1. Astley, O. M., E. Chanliaud, A. Donald and M. J. Gidley, 2001. Structure of Acetobacter cellulose composites in the Hydrated State. Intl. J. Biol. Macromol., 29: 193-202.

2. Geyer, U., T. Heinze, A. Stein, D. Klemm, S. Marsch, D. Schumann and H. P. Schmauder, 1994. Formation, Derivatization and Applications of Bacterial Cellulose . Intl. J. Biol. Macromol., 16: 343-347.

3. Klemm, D., D. Schumann, U. Udhardt and S. Marsch, 2001. Bacterial Synthesized CelluloseArtificial Blood Vessels for Microsurgery. Prog. Ploym. Sci., 26:1561-1603.

4. Lynd, L.R., P.J. Weimer, H. Willem, V. Zyl and I.S. Pretorins, 2002. Microbial cellulose utilization: Fundamentals and biotechnology. Microbio. Mol. Biol., 66:506-577.

5. Rainer, J. and F. Luiz, 1998. Production and application of microbial cellulose. Polymer Degradation and Stability, 59: 101-106.

6. Valla, S., D.H. Coucheron and J. Kjosbakkeng, 1987. The plasmids of Acetobacter xylinum and their interaction with the host chromosome. Mol. Gen. Genet., 209: 412-15
7. Hestrin, S. and M. Schramm, 1954. Synthesis of Cellulose by Acetobacter xylinum. Biochem. J., 58: 163-166.

8. Tahara, N., H. Yaho and F. Yoshinaga, 1997. Two types of cellulase activity produced by a cellulose producing A strain. J. Ferment. Bioeng., 83: 389-392.

9. Sambrook, J., E. Fritsch and T. Maniatis, 2001. Molecular Cloning: A Lab. Manual. Cold Spring Harbor Lab., Cold Spring Harbor, New York.

10. Birnboim, H. C., 1983. A rapid alkaline extraction method for the isolation of plasmid DNA. Methods Enzymol., 100: 243-255.

11. Birnboim, H.C. and J. Doly, 1979. A rapid alkaline extraction procedure for screening recombinant plasmid DNA. Nucleic Acids Res., 7: 1513-1523.

12. Saxena, I. M., K. Kudlicka and R.M. Brown, 1994. Characterization of genes in the cellulose synthesizing operon (acs operon) of Acetobacter xylinum implications for cellulose crystallization. J. Bacteriol., 176: 5735-5752.

13. Tonochi, N., N. Tahara and Y. Kojima, 1997. A beta glucosidase gene downstream of the cellulose synthase operon in cellulose producing Acetobacte. Biosci. Biotechnol. Biochem., 61: 1789-90.

14. Umeda, Y., A. Hirano and M. Ishibashi, 1999. Cloning of cellulose synthase genes from Acetobacter xylinum JCM 7664. DNA Res., 6: 109-115.

15. Kawano, S., K. Tajima, Y. Liemor, H. Yamashit and T. Erata. 2002. Cloning of cellulose synthesis related genes from Acetobacter xylinum ATCC 23769 and ATCC 53582. DNA Res., 9: 149-156.

16. Friedman, A.M., S.R. Long, S.E. Brown, W.J. Buikema and F.M. Ausubel, 1982. Construction of a broad host range cosmid cloning vector and its use in the genetic analysis of Rhizobium mutants. Gene, 18: 289-296.

17. Keen, N. T., S. Tamaki, D. Kobayashi and D. Trollinger, 1988. Improved broad-host-range plasmids for DNA cloning in gram-negative bacteria. Gene, 70: 191-197. 